\title{
Small-scale fishers' perception of the implementation of the EU Landing Obligation regulation in the outermost region of the Azores
}

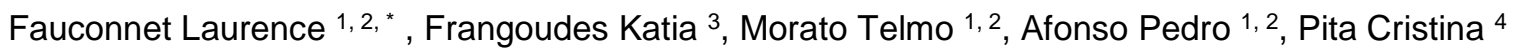

1 Instituto Do Mar (IMAR) and Okeanos Research Unit, Universidade Dos Açores, Departamento de

Oceanografia e Pescas, 9901-862, Horta, Portugal

2 Marine and Environmental Sciences Centre (MARE), Universidade Dos Açores, 9901-862, Horta,

Portugal

3 Univ Brest, Ifremer, CNRS, UMR 6308, AMURE, IUEM, 29280, Plouzane, France

4 Department of Environment and Planning \& Centre for Environmental and Marine Studies (CESAM), University of Aveiro, Campus Universitário de Santiago, 3810-193, Aveiro, Portugal

*Corresponding author : Laurence Fauconnet, email address : laurence.fauconnet@gmail.com

\begin{abstract}
:
The archipelago of the Azores (mid-north Atlantic Ocean) is an outermost region of the European Union (EU) in which small-scale fisheries are a strong component of the local economy. Bottom longlining and handlining are the most important Azorean fisheries in landing values, fishing vessels and fishers. Despite their high selectivity and low discards, these fisheries can be highly impacted by the implementation of the Landing Obligation (LO). Semi-structured interviews were conducted with Azorean small-scale fishers to document their perceptions about discards and the LO, and to ascertain the mitigation measures they already implement or could further implement to avoid unwanted catch. Results suggest that most fishers strongly oppose the LO, perceiving it as inadequate to their fisheries. Several discard avoidance measures are already commonly used by most fishers, of which hook size and changing areas where there are too many undersized or over-quota individuals, are believed to be the most efficient. Additional measures to further improve selectivity and avoid unwanted catch appear limited. The recent conversion of many bottom longliners to handlining and the exemptions foreseen as part of the LO for the region might help Azorean fishers to mitigate the potential impacts of the LO.
\end{abstract}

\section{Highlights}

Fishers' perceptions about the LO and potential mitigation measures were appraised. Most fishers strongly opposed the LO, perceived as inappropriate to their fisheries. Hook size and changing areas are already commonly used to avoid unwanted catch. Conversion of longliners to handliners might help mitigate the impacts of the LO. O Options to further improve selectivity and avoid unwanted catch seem limited.

Keywords : EU landing obligation, Small-scale Fishers, Outermost region, Discard avoidance, Hooks-andlines, Deep-sea fishery 


\section{Introduction}

The European Union (EU) Common Fisheries Policy (CFP) aims to conserve marine biological resources and manage EU fisheries. The CFP also ensures that fishing and aquaculture activities contribute to long-term environmental, economic, and social sustainability. Discards, the portion of the catch returned to the sea either dead or alive for whatever reason (FAO, 1996), is an important factor in this equation, and many claimed a ban on discards during the public consultation for the CFP reform Green Paper. This demand was partly taken into account in the EU regulation 1380/2013-with the introduction of article 15, the so-called Landing Obligation (LO), which demands all catches of species subject to catch limits to be landed, recorded, and counted against the quotas. The LO includes the possibility of certain exemptions, including species for which fishing is prohibited by the Commission or with a high survival rate subject to scientific proof. Additionally, the de minimis exemption, a discard allowance of up to $5 \%$ of the annual catch of quota species, applies if it is proven that the fishery cannot further improve its selectivity or if the costs of handling the unwanted catch are disproportionate.

The LO implementation process started in 2015 and is foreseen to be complete in 2019 across all member states and fleets, despite the fact that EU member states, regions, and fisheries are widely diverse. The expectations are that a combination of the LO and restrictions to consumption for non-human purposes will encourage fishers to avoid unwanted catch. Yet, for this goal to be achieved, sufficient incentives would have to be given for fishers to comply (Condie et al., 2014), including high level of surveillance/proper enforcement (Batsleer et al., 2016; Condie et al., 2013) and flexibility in finding their own technical and tactical solutions to reduce unwanted catch (Catchpole et al., 2017). Other recent studies showed that the LO is still unpopular within the fishing sector but many fishers are willing to take measures to reduce unwanted catch and discarding practices (de Vos et al., 2016; Fitzpatrick et al., 2019).

The LO poses multiple challenges for European fisheries, many of which are essentially multispecific and multigear (Catchpole et al., 2017; Sardà et al., 2015). These challenges are further accentuated by the tight implementation timeframe when compared to other cases worldwide (Borges et al., 2016). Negative short term effects in the economic performance of many fisheries can be expected (Alzorriz et al., 2018; Prellezo et al., 2016), including the risk of developing a black market for undersized fish (Bellido et al., 2017) and increased fishing mortality due to quota uplifts coupled with continued discarding (Borges et al., 2016). Yet, despite a recognized need for regional tailoring, the LO is very much a "one-fits-all" rule. In particular, the LO may be unsuited for smallscale fisheries for which it could have detrimental social, economic and ecological impacts (Veiga et al., 2016; Villasante et al., 2016a, 2016b, 2019). Thus, its implementation can raise concerns in the EU outermost regions, characterised by multispecific small scale fisheries and limited capacity to handle unwanted catch on board or on land.

The archipelago of the Azores, a Portuguese autonomous region located in the mid-North Atlantic, $1500 \mathrm{~km}$ west of mainland Europe and $3000 \mathrm{~km}$ from North America, is one of 
such regions. Fisheries are managed under the CFP with implemented minimum landing sizes (MLS) and quotas, but several additional measures have also long been implemented by the local (Azorean) fisheries authorities to better take into account regional specificities. Azorean fisheries were only scheduled to be under the LO from 2019 onward. Given that local fisheries are dominated by the small-scale bottom longlining and handlining, there is a general perception that the LO can potentially affect these fisheries and result in strong negative socio-economic impacts for the whole region. This paper aims to gauge the perceptions of Azorean bottom fishers and other relevant stakeholders about the impacts of the LO implementation, and to document the mitigation measures they already implement or could be willing to implement in order to avoid unwanted catch.

\section{Methodology}

\subsection{Bottom fisheries in the Azores}

Composed of nine islands widespread over $600 \mathrm{~km}$, the Azores archipelago occupies a vast territory with an Exclusive Economic Zone (EEZ) of approximately 1 million $\mathrm{km}^{2}$ (Figure 1). The bottom hooks-and-lines gear (handline and longline) is the most important fishery in the region both in terms of landed value, number of boats and direct jobs (Carvalho et al., 2011). With over $80 \%$ of the vessels smaller than $12 \mathrm{~m}$, it is considered a small scale fishery operating all year round from coastal areas to offshore seamounts (Diogo et al., 2015; Morato et al., 2013, 2008). The average estimated catch (including unreported and discarded) was ca. $4500 \mathrm{t} \cdot \mathrm{year}^{-1}$ over the 2008-2017 period (Fauconnet et al., 2019; Pham et al., 2013) for an average 18-29 million $€$ annual ex-vessel value, about $76 \%$ of all landed value in the Azores (Carvalho et al., 2011; Morato, 2012).

Since 2000, the use of bottom longlines has significantly been reduced and many smaller boats switched to handlining. Handlines are usually composed of vertical lines with 1 to 200 hooks per set and generally operate between 50 and $600 \mathrm{~m}$ depth. Longlines are horizontal lines deployed close to the seabed down to $1200 \mathrm{~m}$ depth with up to 1500 hooks per set in the small-scale fleet and 2500 hooks per set in the large-scale fleet (Carvalho, 2010). Catches usually include over 20 species of commercial value but the most important $(>50 \%)$ are blackspot seabream (Pagellus bogaraveo), wreckfish (Polyprion americanus), alfonsinos (Beryx decadactylus and B. splendens), bluemouth rockfish (Helicolenus dactylopterus) and European conger (Conger conger). The bottom fishery was estimated to discard $10.3 \%$ (447 $\mathrm{t}^{\cdot}$ year $^{-1}$ ) of its total catch weight (Fauconnet et al., 2019). Most discarded species included smaller individuals of silver scabbardfish (Lepidopus caudatus), European conger and bluemouth rockfish due to their lower economic value. Several quota-managed species were also discarded in higher quantities, namely blackspot seabream, alfonsinos and deep-water sharks. 


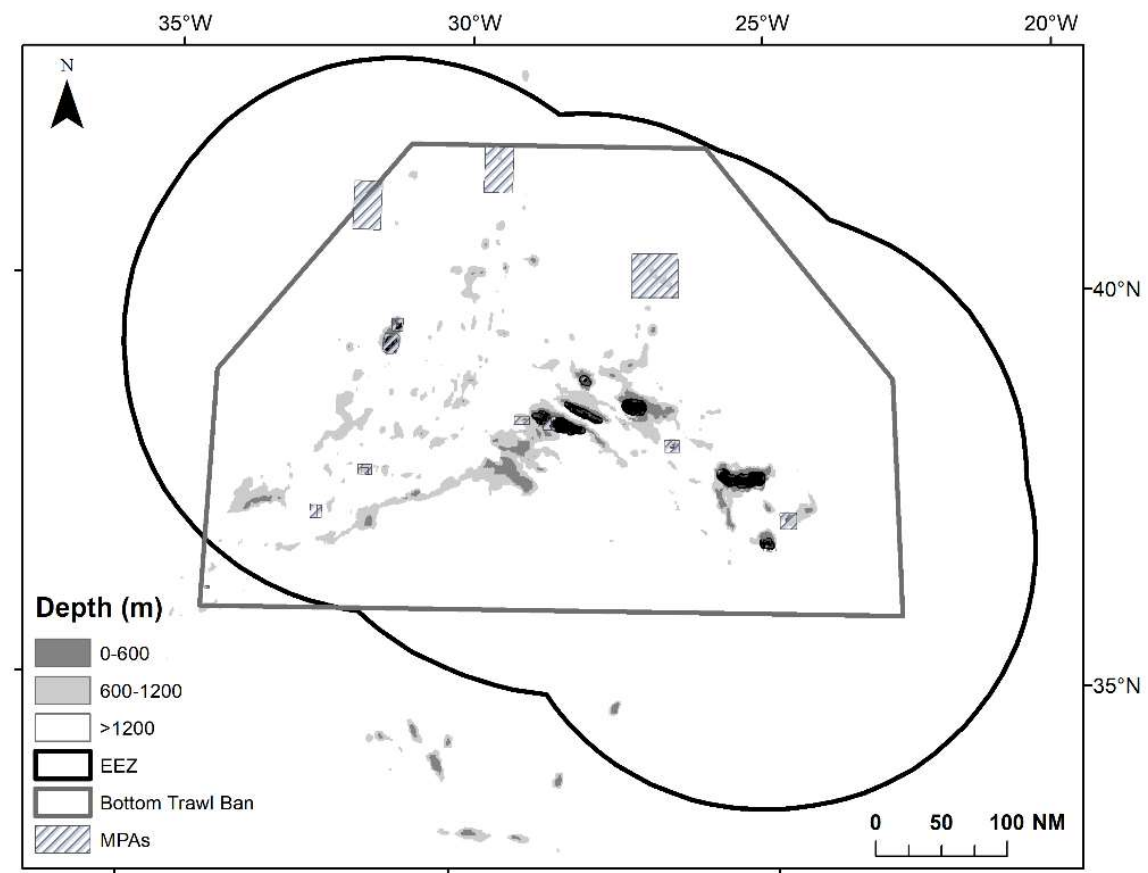

Figure 1. Bathymetry and main current fishing regulations within the Azores Economic Exclusive Zone (EEZ). [2-column fitting image].

\subsection{Fisheries management in the Azores}

The regional government of the Azores was given local control over their fisheries in 1976 although this autonomy was always limited by the separation of powers between the region, mainland Portugal and the European Union (Lewis and Williams, 1994; Neilson et al., 2014). Responsibility for implementing regional fisheries policies lies with the Regional Secretary of the Environment and Fisheries (SRAM) whereas the Regional Fisheries Inspection is responsible for programming, coordinating and executing enforcement and control of the fishing activity in the Azores (Carvalho, 2010).

The current fisheries management in the Azores is based on the EU-CFP, implemented primarily through total allowable catches (TACs) for various species (Table 1) (EC Reg. 2340/2002; EC Reg. 2270/2004). The implementation of this system follows some locally set specific rules designed to better manage quotas, optimize the landed value and limit the socio-economic impacts. Blackspot seabream (the most valuable species) quotas can be individually transferable (under certain conditions), collective or a combination of both depending on the island. For all other species the quotas are pooled. The alfonsino quota, which has been reduced and reached earlier in recent years (Table 1), includes both Beryx splendens and $B$. decadactylus and is managed as whole across the archipelago (as all other species). However, upon reaching $80 \%$ of the Beryx quota, landing of B. splendens become forbidden while a $5 \%$ of total catch of the less frequent yet more valuable $B$. decadactylus is allowed (the so-called " $80 \%$ notice"). A zero TAC has been implemented for deep-water sharks since 2010 for 13 species (Table 1, EC Reg. 1359/2008) as well as for orange roughy (Hoplostethus atlanticus). This latter has been declared a "prohibited 
species" since 2017 by the EC (EC Reg. 2016/2285) implying that under the LO all catch must be discarded. In 2019, zero TAC deep-water sharks also became "prohibited species", but as they were under a zero TAC at the time of the interviews, "zero TAC" will be used throughout the manuscript for this group.

Apart from quotas, the regional government of the Azores has implemented multiple technical and spatial measures over the years, such as minimum landing sizes or weights (some examples are shown in Table 1), minimum mesh and hook sizes, gear ban or licence limitation, and area/seasonal closures. A good example is the deep-sea trawling ban, which later became an EC regulation (EC Reg. 1568/2005) for the Azores (Figure 1), Madeira and Canary Islands. Some areas have been fully closed to commercial and recreational fishing, including the Condor and Formigas seamounts (Figure 1). Other spatial restrictions have been implemented for bottom longliners and handliners as follows: i) longliners are not allowed to fish within $3 \mathrm{~nm}$ from shore, ii) longliners may only fish from 3 to $6 \mathrm{~nm}$ from shore of their island of registry/home ports, and iii) handliners are not allowed within $1 \mathrm{~nm}$ from the coast if $\leq 14 \mathrm{~m}$ in length, $3 \mathrm{~nm}$ if $>14 \mathrm{~m}$, and $30 \mathrm{~nm}$ if vessels $>24 \mathrm{~m}$. Finally, there was a full seasonal closure for blackspot seabream in (spawning) winter months from 2015 to 2017.

\subsection{Data collection}

Twenty-one semi-structured interviews with fishers were conducted in November/December 2016 in the islands with the highest number of bottom longline and handline vessels (São Miguel, Terceira, Faial, and Pico) to gauge their perceptions on the impacts of the implementation of the LO and to ascertain the (alternative) practices already in place or potentially to be put in place to avoid unwanted catch. Interviews were carried out across the four islands with boat owners or skippers, all men, employing different gear modalities and operating vessel sizes in order to capture the fishery (Table 2 ). This sample size was considered sufficient to carry out qualitative analyses of the data since 20 interviews has been showed as a sufficient sample size for in-depth semistructured interviews (Morgan et al., 2002; Tashakkori and Teddlie, 2003). Some further interviews were also conducted with other relevant stakeholders including representatives of the Fisheries Directorate, the Azores fish auction (LOTAÇOR) and the fishers' associations. Interviewees were selected upon expert opinion consultation or during visits to the fishing harbours. Interviews lasted around one hour and were carried out individually, on a voluntary basis, mostly on the dock, but occasionally in meeting rooms. 
Table 1. Summary of changes in management measures affecting the bottom longline and handline fisheries, and quota species they catch, since 2010. DLL stands for the deep-water drifting longline targeting black scabbardfish fishery.

\begin{tabular}{|c|c|c|c|c|c|c|c|c|c|c|}
\hline Measure & Species & 2010 & 2011 & 2012 & 2013 & 2014 & 2015 & 2016 & 2017 & 2018 \\
\hline Quota & Beryx spp. & $214 t$ & $214 t$ & $214 t$ & $\begin{array}{l}203 \mathrm{t} ; \\
\text { " } 80 \% \\
\text { notice"* }\end{array}$ & $\begin{array}{c}193 \mathrm{t} ; \\
\text { "80\% } \\
\text { notice" }\end{array}$ & $\begin{array}{l}193 \mathrm{t} ; \\
\text { "80\% } \\
\text { notice" }\end{array}$ & $\begin{array}{l}193 \mathrm{t} ; \\
\text { "80\% } \\
\text { notice" }\end{array}$ & $\begin{array}{c}182 \mathrm{t} ; \\
\text { "80\% } \\
\text { notice" }\end{array}$ & $\begin{array}{l}182 \mathrm{t} ; \\
\text { "80\% } \\
\text { notice" }\end{array}$ \\
\hline MLS & Beryx splendens & - & - & - & - & - & $250 \mathrm{~g}$ & $250 \mathrm{~g}$ & $30 \mathrm{~cm}$ & $30 \mathrm{~cm}$ \\
\hline MLS & Beryx decadactylus & & & & & & $250 \mathrm{~g}$ & $250 \mathrm{~g}$ & $35 \mathrm{~cm}$ & $35 \mathrm{~cm}$ \\
\hline Quota & Pagellus bogaraveo & $1116 \mathrm{t}$ & $1116 \mathrm{t}$ & $1116 \mathrm{t}$ & $1104 \mathrm{t}$ & $904 t$ & $678 \mathrm{t}$ & $507 \mathrm{t}$ & $507 \mathrm{t}$ & $507 \mathrm{t}$ \\
\hline MLS & Pagellus bogaraveo & $25 \mathrm{~cm}$ & $25 \mathrm{~cm}$ & $25 \mathrm{~cm}$ & $25 \mathrm{~cm}$ & $25 \mathrm{~cm}$ & $30 \mathrm{~cm}$ & $32 \mathrm{~cm}$ & $33 \mathrm{~cm}$ & $33 \mathrm{~cm}$ \\
\hline $\begin{array}{l}\text { Seasonal } \\
\text { closure }\end{array}$ & Pagellus bogaraveo & - & - & - & - & - & $\begin{array}{l}15 / 01 \text { to } \\
29 / 02\end{array}$ & $\begin{array}{l}15 / 01 \text { to } \\
29 / 02\end{array}$ & $\begin{array}{l}15 / 01 \text { to } \\
31 / 01^{* *}\end{array}$ & - \\
\hline Quota & Phycis blennoides & $36 \mathrm{t}$ & $36 \mathrm{t}$ & $36 \mathrm{t}$ & $36 \mathrm{t}$ & $36 \mathrm{t}$ & $45 \mathrm{t}$ & $45 \mathrm{t}$ & $40 \mathrm{t}$ & $36 \mathrm{t}$ \\
\hline Quota & $\begin{array}{l}\text { Hoplostethus } \\
\text { atlanticus }\end{array}$ & TAC 0 & TAC 0 & TAC 0 & TAC 0 & TAC 0 & TAC 0 & TAC 0 & $\begin{array}{l}\text { Prohibited } \\
\text { species }\end{array}$ & $\begin{array}{l}\text { Prohibited } \\
\text { species }\end{array}$ \\
\hline Quota & Aphanopus carbo ${ }^{* * *}$ & $3311 \mathrm{t}$ & $3311 \mathrm{t}$ & $3311 \mathrm{t}$ & $3659 \mathrm{t}$ & $3689 \mathrm{t}$ & $3659 \mathrm{t}$ & $3659 \mathrm{t}$ & $3294 \mathrm{t}$ & $2965 \mathrm{t}$ \\
\hline Quota & $\begin{array}{l}13 \text { taxa }^{* * * *} \text { of deep- } \\
\text { water sharks (DWS) }\end{array}$ & $\begin{array}{l}\text { Implementation } \\
\text { of the TAC } 0 ; \\
\text { allowance of } \\
\text { max } 10 \% \text { of } \\
2009 \text { quota } \\
(10 t) \text { as } \\
\text { bycatch }\end{array}$ & $\begin{array}{l}\text { TAC } 0 ; \\
\text { allowance of } \\
\max 3 \% \text { of } \\
2009 \text { quota } \\
\text { (10t) taken } \\
\text { as bycatch; } 4 \\
\text { new species } \\
\text { added }\end{array}$ & TAC 0 & $\begin{array}{l}\text { TAC 0; } \\
\text { Galeus } \\
\text { melastomus } \\
\text { removed; } \\
\text { Centrophorus } \\
\text { lusitanicus } \\
\text { added }\end{array}$ & TAC 0 & TAC 0 & TAC 0 & $\begin{array}{l}\text { TAC } 0 ; \\
\text { allowance of } \\
10 \text { t of } \\
\text { bycatch only } \\
\text { of DLL; no } \\
\text { directed } \\
\text { fishery } \\
\text { allowed }\end{array}$ & $\begin{array}{l}\text { TAC } 0 \text {; } \\
\text { allowance of } \\
10 t \text { of } \\
\text { bycatch only } \\
\text { of DLL; no } \\
\text { directed } \\
\text { fishery } \\
\text { allowed }\end{array}$ \\
\hline
\end{tabular}

* "80\% notice" occurs when $80 \%$ of the shared Beryx spp. quota has been achieved and implies a 5\% catch limit for B. decadactylus and a closure for B. splendens.

** A new regulation 13/2017 approved by the Regional Government of the Azores revoked the seasonal closure for Pagellus bogaraveo.

*** The black scabbard fish quota presented here is for areas XIII, IX and X which includes mainland Portugal and the Azores. The Madeira quota is included in the CECAF 34.1.2. area.

${ }^{* * * *}$ List of deep-water sharks (DWS) for which a zero TAC has been applied since 2010: Apristurus spp., Centrophorus granulosus, Centrophorus squamosus, Centroscyllium fabricii, Centroscymnus coelolepis, Centroscymnus crepidater, Dalatias licha, Deania calcea, Etmopterus princeps, Etmopterus spinax, Galeus melastomus, Galeus murinus, Somniosus microcephalus.

${ }^{* * * * *}$ Chlamydoselachus anguineus, Hexanchus griseus, Oxynotus paradoxus, Scymnodon ringens added. 
Table 2. Distribution of the number of fishing vessels using hooks-and-lines and of the number of interviews conducted with handliners (HL) and longliners (LL) by vessel size category (in meters) in the 4 main islands for those fisheries.

\begin{tabular}{|c|c|c|c|c|c|c|c|}
\hline \multirow{2}{*}{ Island } & & \multirow{2}{*}{$\begin{array}{l}\text { Gear } \\
\text { type }\end{array}$} & \multicolumn{4}{|c|}{ Vessel size } & \multirow{2}{*}{ Total' } \\
\hline & & & $<10 \mathrm{~m}$ & $10-12 m$ & $12-18 m$ & $>18 \mathrm{~m}$ & \\
\hline \multirow{3}{*}{ Faial } & $\mathbf{N}^{\mathbf{0}}$ vessels & & 42 & 6 & 4 & - & 52 \\
\hline & \multirow{2}{*}{$\mathbf{N}^{0}$ interviews } & $\mathrm{HL}$ & 4 & - & 1 & - & \multirow{2}{*}{6} \\
\hline & & LL & - & - & 1 & - & \\
\hline \multirow{3}{*}{$\begin{array}{c}\text { São } \\
\text { Miguel }\end{array}$} & $\mathrm{N}^{\mathbf{0}}$ vessels & & 87 & 46 & 24 & 4 & 161 \\
\hline & \multirow{2}{*}{$\mathbf{N}^{0}$ interviews } & $\mathrm{HL}$ & 1 & - & - & - & \multirow{2}{*}{8} \\
\hline & & LL & 1 & 3 & 2 & 1 & \\
\hline \multirow{3}{*}{ Terceira } & $\mathrm{N}^{\mathbf{0}}$ vessels & & 71 & 8 & 7 & - & 86 \\
\hline & $\mathbf{N}^{0}$ interviews & $\mathrm{HL}$ & 2 & - & - & - & \multirow{2}{*}{5} \\
\hline & s miterviews & $\mathrm{LL}$ & 1 & 1 & 1 & - & \\
\hline \multirow{2}{*}{ Pico } & $\mathrm{N}^{\mathbf{0}}$ vessels & & 67 & - & - & - & 67 \\
\hline & $\mathbf{N}^{0}$ interviews & HL & 3 & - & - & - & 3 \\
\hline
\end{tabular}

* the total number of vessels from interviewed fishers as one interviewed owned two vessels of different size categories

The interviews focused on several topics, including:

1) Current discard practices, including which species are discarded, how much and the reasons for discarding;

2) Current knowledge about, and perceived impacts of the LO, namely the understanding of the LO and its regulation, the perceived impacts on fishing activities, and the views on the use of unwanted catch for purposes other than direct human consumption; topic appraised with fishers and other stakeholders;

3) Discard avoidance practices

a. Avoidance of unwanted catch, namely technical (gear-based) and tactical (strategy-based) practices, including already implemented and new potential measures;

b. Avoidance of zero TAC species, namely potential technical and tactical practices to reduce unwanted catch of deep-water sharks;

4) Perceptions and practices to increase the survival of unwanted catches, namely the perceived likelihood of survival of discarded species, the potential measures to increase their survival, and the corresponding willingness to adjust practices;

5) Management measures to mitigate the likely impacts of the LO, namely spatial and temporal measures, technical measures, quota based measures and other governance measures. 
Other topics directly relevant to the deep-water hooks-and-lines fisheries were also covered, including the fishers' expectations from scientific research.

Interviews were carried out in Portuguese then translated into English, transcripted and analysed. Interviews were divided in themes as to allow analysis. To summarize answers, different categories were developed based on their responses to open-ended questions addressed during semi-structured interviews. Main points were summarized in table format to highlight key messages, similarities and contrasts, while avoiding losing important personal views. Although great attention has been given to this process, it cannot be fully ascertained that this categorising and interpretation did not reduce the scope of the collected data.

\section{Results}

\subsection{Current practices regarding unwanted catch}

All fishers acknowledged discarding part of their catch. Discard rates vary according to gear type and fishers from very low to over $50 \%$. Discards were generally mentioned to be lower in handlining versus longlining and in individual quota islands versus collective quota islands, as fishers seem to fish as much as they can before the quota is reached in the later. Catch undersized fish was the most mentioned reason for discarding (Table 3), especially for blackspot seabream (MLS increased in 2016 from 29 to $32 \mathrm{~cm}$ ) and bluemouth rockfish. Low market value was the second most frequent reason, even if some of these species are eventually kept for consumption. Quota limitations were another common reason for discarding, mostly for alfonsinos and blackspot seabream, but also zero TAC deep-water sharks. Discard of damaged catch was also mentioned but the LO does not apply to this practice. The reasons for discarding as mentioned by fishers were mostly in accordance with observer data collected by the national observer programme for discards and by the results of the EU H2020 Discardless project (Canha, 2013; Fauconnet et al., 2019).

Many fishers reported discarding most fish alive to the water, but also recognised using part of the unwanted catch for bait (as it decreases expenses) or for own consumption (onboard or back on land). Some also reported that part of unwanted catch is illegally landed and sold (e.g., undersized valuable fish). These practices are acceptable by the local society as it represents a perceived compensation for the low income of (some) crew members. Some boat owners argued that the LO could actually constitute an incentive for them to discard, as crew members would never accept not to bring this catch back home to feed their family or get some extra money. While the essence of discarding was frequently agreed with - "If the fish survives, discard is a good think, it increases the stock" - various fishers assumed to dislike discarding as they consider it a waste - "It is a sin to discard already dead fish", "What is the point of putting them back in the water if they are already dead?". Many fishers disagreed to land unwanted catch if it cannot go to human consumption, as they would prefer to give it to charity institutions. 
Table 3. Summary of current discard practices mentioned by fishers of the bottom hooksand-lines fisheries. NA is no answer.

\begin{tabular}{|c|c|c|c|c|c|c|c|}
\hline & Discard & & & & son for discarding & & \\
\hline & & Quota & MLS & $\begin{array}{l}\text { Protected specie } \\
\text { (or 0 TAC) }\end{array}$ & $\begin{array}{l}\text { Low market value I } \\
\text { (species) }\end{array}$ & $\begin{array}{l}\text { Low market value } \\
\text { (small size) }\end{array}$ & Damaged \\
\hline Yes & 21 & 5 & 15 & 4 & 9 & 6 & 1 \\
\hline No & 0 & 1 & 2 & 0 & 0 & 0 & 0 \\
\hline NA & 0 & 15 & 4 & 17 & 12 & 15 & 20 \\
\hline$\%$ Yes & $100.0 \%$ & $23.8 \%$ & $71.4 \%$ & $19.0 \%$ & $42.9 \%$ & $28.6 \%$ & $4.8 \%$ \\
\hline
\end{tabular}

\subsection{Current knowledge and perceived impacts of the LO}

The interviews were the first time many fishers even heard about the LO. Even among those that had already heard about it, including the members of fishers' organizations, mentioned they did not fully understand the details of the LO, how it will be applied and the implications it will have for them.

After the LO content was explained to them, most fishers showed some degree of disagreement and others even said the regulation "does not make any sense" for the smallscale deepwater hooks-and-lines fishery. "What is the logic?", "What does it matter if there is no incentive to comply?". Most of them expressed worries about the impacts the LO could have on their activities, especially regarding the problems of choke species and the obligation to stop fishing once the quota is reached. "It is going to destroy the whole fishery, even faster", "It is not going to help for the sustainability of the fisheries. It will not solve the problems of the sector" were the main arguments put forward. Most fishers, as well as other stakeholders, felt the LO is not adequate to the specificities of the local fisheries as they are already using the most selective fishing gears across Europe, and because it is an isolated region with limited job alternatives. Many fishers admitted not to be willing to comply with the LO, and suspected that nobody would, and that no control at sea would take place to enforce it neither "Do you really think the people are going to respect this?".

Many fishers strongly disliked the fact that this "landing" of unwanted catch will count against their quota, and said it may result as an incentive to discard: "What is the incentive to comply then?", "I don't want to work for free", "Counting against the quota is being punished by complying with the law". Again, most fishers specially opposed the fact that they would not be able to use this catch for direct human consumption: "To do what then? Go for the garbage bin? To do fishmeal? No way!". Together with other interviewed stakeholders, they mentioned that there is currently no industry in the Azores able to process the unwanted catch, and there are no prospects of having such industry in the near future. The geographic dispersion of the Azores islands was also perceived as an additional obstacle for making use of the landed unwanted catch because of the resulting costs in transport to the main islands where processing could eventually take place. Some 
fishers also pointed out that there could be lack of storage space on-board the smaller fishing vessels, especially if different compartments are imposed for different catch categories. Even if the amount of discards is small, it would still require extra work and increased expenses, and they were not willing to work longer or support extra costs if they could not sell this catch afterwards.

Table 4. Summary of the bottom hooks-and-lines fishers' responses concerning the Landing Obligation regulation. NA is no answer.

\begin{tabular}{lcccc}
\hline Question & \multicolumn{4}{c}{ Responses } \\
& Yes & No & NA & $\%$ Yes \\
\hline Heard of the LO & 10 & 10 & 1 & $47.6 \%$ \\
Agree with the LO & 2 & 18 & 1 & $9.5 \%$ \\
\hline
\end{tabular}

\subsection{Discard avoidance practices}

\subsubsection{Technical measures}

There was a strong consensus among interviewed fishers that large hook size is an efficient way to reduce the amount of undersized individuals in the catch (Table 5), even though it does not completely prevent it. "The small and big fish are mixed but with the big hooks we catch less small fish." Most fishers declared using hook size $\mathrm{n}^{\circ} 9$ (the legal size with $12 \mathrm{~mm}$ in gape width) or larger, even though a few recognized to use smaller hooks. Although fishers used larger hooks when targeting larger fish or larger species such as wreckfish and conger, they otherwise showed limited willingness to use larger hooks as a mitigation measure (Table 5). Some argued that the additional costs (in hooks and bait) of using larger hooks are too high in comparison with the foreseen benefits, while others do not believe it may significantly decrease the unwanted catch - "Even more selective?".

A few fishers have already changed the hook shape to avoid unwanted catch using slightly more curved J-shaped hooks. They argued that this "Spanish" hook seemed efficient in reducing unwanted catch. Reducing the number of hooks in longlining got little support, with some fishers stating they would only be willing to do so if there were some incentives, for example if they were allowed to fish within $3 \mathrm{~nm}$ from the coast. Three out of the 11 interviewed handline fishers had recently switched from longline. These fishers argued that the handlining benefits of catching larger fish sold at a higher price, reduced expenses (in crew, hooks, bait, and fuel) and increased flexibility in fishing tactics and techniques - "it is an active fishing gear"- largely compensates its smaller catches. Overall, handlining is perceived as more cost-effective and most handliners expressed the opinion that all longliners should be converted to handliners - "handline is the most selective fishing gear". 
Table 5. Summary of interview responses on the use of different hook sizes to avoid unwanted catch by the bottom hooks-and-lines fishers. NA is no answer.

\begin{tabular}{|c|c|c|c|c|c|c|c|}
\hline \multirow[t]{2}{*}{$\begin{array}{l}\text { Hook size } \\
\text { (gape width) }\end{array}$} & \multirow[t]{2}{*}{$\begin{array}{l}\text { No. of } \\
\text { fishers }\end{array}$} & \multicolumn{3}{|c|}{$\begin{array}{c}\text { Avoidance of } \\
\text { unwanted catch }\end{array}$} & \multicolumn{3}{|c|}{$\begin{array}{c}\text { Willing to use larger } \\
\text { hooks }\end{array}$} \\
\hline & & Yes & No & NA & Yes & No & NA \\
\hline $12 \mathrm{~mm}$ (legal size) & 4 & 3 & 0 & 1 & 0 & 1 & 3 \\
\hline \multicolumn{8}{|l|}{$12 \mathrm{~mm}$ when targeting seabream; } \\
\hline$>12 \mathrm{~mm}$ when targeting larger species & 3 & 2 & 0 & 1 & 0 & 1 & 2 \\
\hline$>12 \mathrm{~mm}$ & 8 & 8 & 0 & 0 & 0 & 2 & 6 \\
\hline$<12 \mathrm{~mm}$ & 2 & 1 & 1 & 0 & 0 & 1 & 1 \\
\hline Unknown & 4 & 2 & 0 & 2 & 0 & 0 & 4 \\
\hline$\%$ of answers & & $76.2 \%$ & $4.8 \%$ & $19.0 \%$ & $0.0 \%$ & $23.8 \%$ & $76.2 \%$ \\
\hline
\end{tabular}

\subsubsection{Tactical measures to avoid unwanted catch}

Some fishers avoid fishing areas known for having unwanted catch but avoiding areas with large abundances of juveniles of blackspot seabream was perceived as being very difficult, if not impossible (Table 6). They stated that small and large individuals are concurrently found in the same area, and that eventual size segregations may change from one day to the next. While permanent avoidance of specific areas is uncommon, they stated to frequently change fishing areas upon catching high proportions of small individuals or when there are too many deep-water sharks that chase or predate on their target fish. This practice is easier and faster for handliners, as it can be performed after one or two sets, whereas longliners deal with much longer soaking times - "the change of area can only be done the following day".

Several other strategies were stated to be used to avoid unwanted catch, such as avoiding night fishing to avoid predation - "They are hungry at night" - , adapting fishing depths to avoid catching alfonsinos and deep-water sharks in deeper waters, and avoid fishing in the new moon phase to avoid smaller individuals.

Overall, most fishers argued that they are already using the most selective gears available and that they are already doing enough to avoid unwanted catch so most of them did not see what else they could do, or were not willing to do more - "we are not at the bottom of the sea choosing which fish bites the hook".

Table 6. Summary of the tactical measures mentioned by deep-water bottom hooks-andlines fishers to avoid unwanted catch. NA is no answer.

\begin{tabular}{lrrrr}
\hline Questions & \multicolumn{3}{c}{ Responses } & \\
& Yes & No & NA & $\%$ Yes \\
\hline Already avoid fishing areas known for unwanted catch & 7 & 6 & 8 & $33.3 \%$ \\
Difficult to avoid fishing areas known for unwanted catch & 7 & 0 & 14 & $33.3 \%$ \\
Change area when unwanted catch & 13 & 2 & 6 & $61.9 \%$ \\
Adapt fishing depth to avoid unwanted catch & 11 & 5 & 5 & $52.4 \%$ \\
\hline
\end{tabular}




\subsubsection{Avoidance zero TAC species}

One third of the interviewees reported bycatch of deep-water sharks can be quite frequent, many stating they are difficult to avoid "It is not my fault if the shark bites my hook! What can I do?", while over half stated never, or rarely, catching sharks (Table 7). It was noticeable that deep-water shark bycatch is more common with longlines than handlines, mostly due to the later operating shallower, with lighter tackle line more prone to break or be cut by the sharks and reduced number of hooks.

Some fishers declared to actively avoid deep-water sharks because they prey on their hooked catch and make their target species flee. However, the willingness of many fishers to avoid deep-water sharks is limited somehow by their potential use as bait and for liver oil, as a market incentive still remains. There was limited interest in using shark deterrents or different hook type to reduce unwanted shark catch or increase shark survivability, mostly due to concerns about the practicality and costs associated with gear modifications along with the pointlessness of such modifications as fishers believe sharks survival rate is high.

Most fishers considered the abundance of deep-water sharks to be too high and complained of not being allowed to fish them anymore. According to them, those high abundances create an 'ecological unbalance' that also has negative impacts for them.

Table 7. Summary of responses concerning bycatch, uses and handling of deep-water sharks (DWS) by bottom hooks-and-lines fishers. NA is no answer and DIS is discard, LAN is landing.

\begin{tabular}{|c|c|c|c|c|c|c|c|c|c|c|c|}
\hline & \multicolumn{4}{|c|}{ Catch of DWS } & \multicolumn{4}{|c|}{ Use of DWS } & \multicolumn{3}{|c|}{ Handling of DWS } \\
\hline & Yes & Rare & No & NA & DIS & LAN & Bait & NA & 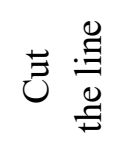 & 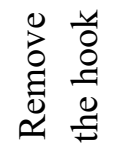 & NA \\
\hline Longline & 5 & 3 & 1 & 1 & 5 & 2 & 1 & 2 & 1 & 2 & 6 \\
\hline Handline & 2 & 6 & 3 & 0 & 6 & 1 & 0 & 4 & 3 & 2 & 7 \\
\hline$\%$ of answers & $33.3 \%$ & $42.9 \%$ & $19.0 \%$ & $4.8 \%$ & $52.4 \%$ & $14.3 \%$ & $4.8 \%$ & $28.6 \%$ & $19.0 \%$ & $19.0 \%$ & $61.9 \%$ \\
\hline
\end{tabular}

\subsection{Measures to increase the survival of unwanted catch}

According to interviewed fishers, the species with the highest rate of survival are blackspot seabream, deep-water sharks and bluemouth rockfish. Handling deep-water sharks is difficult and therefore many fishers prefer to cut the line and sacrifice the hook than "putting their hands in the mouth of a shark". Yet, several fishers admitted to remove the hooks from sharks in order to keep the hooks and reduce expenses.

Survival is perceived to be higher in handlining versus longlining because of its shallower, shorter, and slower hauling fishing mode. Additionally, handliners mentioned 
that, since they have less catch in each fishing set, they have more time to handle it with care. Several fishers mentioned they remove the air from inflated fish to allow them to sink upon release - "it only takes few seconds" - while most longliners argued they do not have enough time to do it. Several expressed the wish to learn from scientists how it should be done.

\subsection{Management measures to mitigate the likely impacts of the LO}

Although some fishers were mostly in favour of the existing closed areas, they were generally against having more, even some specifically targeted to reduce catch of unwanted species or undersized individuals (Table 8). They argued that more closed areas would have the drawback of increasing fishing effort and therefore competition on the already limited fishing grounds. Most fishers also disagreed with real-time dynamic closures, i.e. short-term closures triggered by a certain threshold of unwanted catch (Eliasen and Bichel, 2016), arguing that they would be inefficient in reducing unwanted catch as a result of resource mixing across areas. On the contrary, most fishers agreed with the seasonal closure for blackspot seabream as a biological stop for the species (Table 8), even if this measure does not directly contribute to avoid unwanted catch but rather to manage the quota. Several fishers even criticised the closure not including the whole winter spawning season when they catch large amounts of spawning fish, and were in favour of increasing it even regardless of potential market implications, as long as a financial compensation would be in place. The closure is currently not in place.

Most fishers did not see information sharing across the fleet as a good management measure to avoid unwanted catch (Table 8). They already share information with their family members or close friends, but would not be willing to share information with everyone even to signal areas of undersized individuals as they believe it would only result in increased competition for the "good" fishing grounds.

The existing quota system was seen as a good tool because "there is a need for some system to control the catch", "The system is good. We have to preserve the resources" but some fishers would like it to offer more flexibility or be better adapted to the specificities of the region - "The quotas should be managed by the locals". In São Miguel, the larger island where the quota for blackspot seabream is collective, fishers would prefer to have individual quotas. Instead, fishers were pretty satisfied where the quota is individual, except for a dissent with the quota calculation which is considered unfair to smaller boats. Most fishers were unhappy about how the quota is distributed at the regional level but did not complain about how the TAC is distributed at the international level. One fisher mentioned not to understand the logic and objective of the quota system - "no matter what we do, the result is always a decrease in the quota: when we did not manage to exhaust the blackspot seabream quota, the EU concluded that the abundance was too low and the quota was reduced; but when the quota alfonsino is been exhausted earlier each year, the EU concluded there was too much fishing and the quota has also been reduced". Switching to a multispecific quota system (for blackspot seabream and splendid alfonsino) got little support, as fishers easily manage to avoid catching alfonsinos, the most limiting species, while fishing for blackspot seabream. One fisher strongly 
supported a multi-species and multi-annual (2-3 years) quota, arguing that "flexibility in quota would help for implementation of the $L O$ " and would allow them to better deal with the natural variability of the stocks.

A management regime based on fishing effort could be an alternative to the quota system, however most fishers were not in favour of controlling the number of days at sea as "the (rough) weather already takes care of it" and it would be unfair because it would not account for long navigation times. Most fishers (mainly longliners) were also not in favour of reducing the number of hooks. However, a reduction of the fleet capacity was supported by most fishers who felt that the current number of fishing vessels is too high for the available resources - "To reduce discards, the only efficient measure would be to decrease the number of fishing licences and to impose biological stops. There are too many boats and hooks at sea. Fishing effort should be reduced, fishing mortality should be controlled, and good stock assessments should be performed". Some suggested that a part of the fleet could be shifted to other segments to diversify the fishing activities.

Table 8. Summary of spatial-temporal based management measures in bottom hooksand-lines fishers' responses to mitigate the likely impacts of the LO.

\begin{tabular}{|c|c|c|c|c|c|c|c|c|}
\hline \multirow[b]{2}{*}{ Management measure } & \multicolumn{4}{|c|}{ Agree } & \multicolumn{4}{|c|}{ Willing to have more } \\
\hline & Yes & No & NA & $\%$ Yes & Yes & No & NA & $\%$ Yes \\
\hline No take MPAs & 5 & 2 & 14 & $23.8 \%$ & 0 & 7 & 14 & $0.0 \%$ \\
\hline Real-time closures & 1 & 6 & 14 & $4.8 \%$ & - & - & - & - \\
\hline Seasonal closures & 9 & 4 & 8 & $42.9 \%$ & $3^{*}$ & 4 & 17 & $14.3 \%$ \\
\hline Fleet info sharing & 1 & 5 & 15 & $4.8 \%$ & - & - & - & - \\
\hline
\end{tabular}

${ }^{*}$ if financial compensation is provided

\subsection{Fishers' expectations from scientists}

Some fishers asked scientists to provide data to support an exemption to the LO in the Azores bottom longline and handline fishery or to "prevent the LO from happening in the Azores". Many fishers were interested in having scientific evidence showing that their fishing selectivity is high, that they generate little discards, and that it will be difficult to further improve selectivity. Many fishers were also interested in scientific studies on survival rates of their main target species, which they perceive as high, and several would be willing to bring observers onboard to document high selectivity, small discards and high survival rates. They were also interested in having a manual or a workshop on best handling practices (e.g., how to properly remove air from an inflated fish) to help further increase survival of discards.

On the contrary, once mentioned about scientific maps showing hotspots of unwanted catch (species or undersized individuals) they mostly showed little interest - "Maps of occurrence of small individuals? impossible!" Most fishers did not see the interest of such maps as "we already know where the fish are". Several fishers related such maps with additional spatial fishing closures and were not willing to have more closed areas. 
Other expectations from science included studies to better determine biological closures for blackspot seabream, and to provide scientific evidence of high deep-water shark abundance. The need for improved fisheries catch data including recreational fisheries, and for proper stock assessments were other scientific needs referred by fishers.

\section{Discussion}

\subsection{Perception on discard practices and the $L O$}

Despite the imminent implementation of the LO in 2019, Azorean fishers' awareness and knowledge about the LO was limited or inexistent. This trend is similar to what has already been documented in other areas, especially among small-scale fishers (Christou et al., 2017; Fitzpatrick et al., 2017; Maynou et al., 2018; Veiga et al., 2016; Villasante et al., 2016a, 2016b, 2019). This general ignorance made it difficult for them to completely grasp this new management paradigm, from the previous obligation to discard all undersized individuals and all catch upon exhausting their quota (and being fined for not doing so) to the new obligation to land them. Such paradigm shift seems to be a source of confusion, leading to disbelief and wariness in its merits and to a generally negative appreciation, similarly to many other European regions (de Vos et al., 2016; Maynou et al., 2018; Villasante et al., 2016b, 2019). As in other small-scale fisheries in Europe, they were very skeptical about the benefits of this new regulation and about the general acceptance by fishers (Maynou et al., 2018; Villasante et al., 2016a, 2016b). This negative perception and the foreseen difficulties in enforcement will likely lead to increased noncompliance, especially in the absence of incentives (Veiga et al., 2016; Villasante et al., 2016a, 2016b). Interviews performed in Southern Europe found that $85 \%$ of the interviewees disagreed that the LO will contribute to more sustainable European fisheries (Maynou et al., 2018). The heterogeneous biological, socio-economic and institutional characteristics of the small-scale fisheries in European waters raise serious concerns for the successful implementation of the LO (Villasante et al., 2016b, 2019), including in the Azores.

Small-scale fisheries usually generate low discards due to the use of more selective fishing gears, higher utilization of the catch, and somewhat lower compliance with regulations "generating" discards (i.e. quotas, MLS) (Veiga et al., 2016). Likewise, the high fishing selectivity and a well-established tradition of making the most use of the catch contribute to the low overall discard rate in the Azores bottom longline and handline fishery. Yet, discarding still occurs on a regular basis, with regulatory discards mainly due to MLS or quota exhaustion being preponderant, as in many other European fisheries (e.g., Catchpole et al., 2014, 2005; Poos et al., 2010). Discarding is considered by many Azorean fishers as a waste of resources, especially when the fish is already dead. Also, they are already using different tactical and technical measures to avoid unwanted catch, as documented elsewhere (e.g., Armstrong et al., 1990; Morandeau et al., 2014; Reid et al., 2017). For example, $75 \%$ of fishers interviewed from Southern European small-scale fisheries also claimed to already take steps to avoid unwanted catches regardless of the LO (Maynou et al., 2018; Villasante et al. 2019). 


\subsection{Effectiveness and conformity of mitigation options}

\section{Mitigation unwanted "undersize” catch}

Undersized fish, mostly blackspot seabream, is the main type of discards that Azorean bottom fishers would have to avoid under the LO. They perceived changes in hook size to be the most useful measure in avoiding this discard, despite acknowledging limits in its efficiency. Indeed, hook size was proven to influence size selectivity of blackspot seabream and bluemouth rockfish on bottom longlining (Sousa et al., 1999). As documented elsewhere and for other gear types (Reid et al., 2017), Azores fishers already used mostly the minimum legal hook size or even larger hooks. While hook size $\mathrm{n}^{\circ} 9$ was the most adapted to avoid undersize blackspot seabreams when MLS was $25 \mathrm{~cm}$, the recent increase to $32 \mathrm{~cm}$ rendered this hook size out of adjustment, leading to increased discards of undersized individuals. In other parts of the world, it has been showed that larger J-hooks (6-9) catch larger fish, decreasing the number of fish under MLS and discards with no decrease in legal-sized fish catch (Salierno et al., 2018). However, most fishers were not in favour of increasing the minimum hook legal size, making the avoidance of undersized individuals difficult. An alternative measure to increase selectively in hooks-and-lines bottom fisheries could be an increase in the bait size since this has also been demonstrated to significantly affect size selectivity (Ingólfsson et al., 2017). However, this comes with an additional cost that Azores small-scale fishers are not willing to pay.

The identification of spatial areas where unwanted catch are minimized has been demonstrated to be a feasible management measure (Maina et al., 2018; Paradinas et al., 2016). However, avoiding areas with higher abundance of unwanted catch was considered impossible by most Azorean fishers, claiming that juveniles and adults are mixed in most areas. Yet, larger seabreams are known to occur deeper than juveniles although in lower abundances. Scientific evidence supports the wide geographical distribution of larger juvenile blackspot seabreams, as stated by fishers. The species indeed uses shallow areas, mostly along island coasts, as nurseries before migrating towards deeper areas and adjacent seamounts when adults (but still as undersized subadults), where they become mostly resident (Afonso et al., 2012). During the spawning period, breeders are found across the entire population distribution area .

\section{Mitigation of unwanted "quota" catch}

Quota exhaustion has only been a limiting factor for alfonsinos, with a collective quota that has been reduced and reached increasingly earlier in the recent years (Pham et al., 2013). Despite their high market value, both alfonsinos species are caught in low numbers in the bottom longline and handline fishery. Their catch is especially low in handlining, which usually fishes in depths shallower than those in which alfonsinos are known to occur (Menezes, 1996). Longliners also reported to use vertical (i.e. depth) strategies to avoid unwanted catch of alfonsinos once the quota has been exhausted. Thus, fishers already use this knowledge to limit unwanted catch, even if bycatch still occurs to some extent resulting from the species and sizes vertical overlaps. Vertical avoidance strategies are also applied to avoid zero TAC deep-water sharks. Fishers prefer to avoid them also 
because they predate on their catch and damage their gear. However, deep-sea shark liver oil is still the most common way to extract valuable squalene for use by the pharmaceutical industry (Fagundes et al., 2018), and it is therefore not surprising that some fishers would like to keep fishing for sharks as they think sharks are abundant and create an unbalanced ecosystem. We know of no studies to date in the region or elsewhere to support this idea, and further mitigation measures to avoid deep-water sharks will likely be needed upon the implementation of the LO.

\section{Limited support for further mitigation options}

This study also demonstrates that Azorean fishers have a local ecological knowledge which is largely in agreement with available scientific knowledge, and that they already use this knowledge to avoid unwanted catch. Instead, further avoidance strategies that would be needed to help mitigate the potential socio-economic impacts of the LO appear limited and to have little support.

Similarly, new management measures that could be implemented as mitigation measures mostly received little support. Even if several fishers acknowledged the benefits and need for permanently closed fishing areas, they feel that there are enough closed areas and they were not interested in having more. However, although there are about 44 declared MPAs covering over $10,000 \mathrm{~km}^{2}$ representing about $1.12 \%$ of the Azores EEZ, permanent notake areas are very small, limited in number (Abecasis et al., 2015), and with limited positive effects on commercially exploited fish populations (Afonso et al., 2018). In spite of the large size of the Azores EEZ, potential fishing grounds are limited due to great depths and closing areas will inevitably imply increased fishing pressure on the already limited number of fishing grounds, and on unfished areas. Further, the effectiveness of this measure to avoid unwanted catch may be limited, especially for highly mobile species (Welch et al., 2018). In the case of highly resident species, such as kitefin shark (Fontes et al., 2015), closed areas could effectively protect individuals.

In contrast, seasonal fishing closures such as the biological stop for blackspot seabream, received strong support from fishers, even if many fishers lamented the closure was not at the right time. Indeed, the closure was set in January and February, while evidence shows that spawning of blackspot seabream occurs from January to April (Krug, 1998; Pinho et al., 2014). Real-time closures offer a more flexible alternative than permanent closures that could be better welcomed by fishers as a potential mitigation measure (Dunn et al., 2011; Eliasen and Bichel, 2016; Kraak et al., 2015). Yet, Azorean fishers did not believe real-time closures would work in the region, as the resources are highly variable and they were not willing to share locations of even the "bad fishing grounds" as it would increase competition on the already limited good fishing grounds.

\subsection{Risk of the implementation of the $L O$ and ways forward}

Even if discard amounts are low, the additional costs of having to deal with the landings of unwanted catch are expected to be very high due to wide geographic extent and limited existing infrastructures at landing ports. This is also the case in many EU Member States (Catchpole et al., 2017), but is accentuated by the remoteness of the archipelago. The 
economic losses the LO would inflict on the small-scale fishing sector (e.g., extra costs of handling catch, adapting the vessels) could result in this sector struggling to continue fishing in the Azores as elsewhere (Villasante et al., 2016b). The question of who should pay for those extra costs remains unanswered.

Some Azorean fishers also feared that it would become difficult to find crew willing to work "under LO conditions" (as they tend to take fish home as a complement to low wages), increasing the negative socio-economic impacts of the LO.

It can therefore be expected that the LO will likely bring more negative social, economic and ecological impacts than benefits to Azorean bottom fisheries, at least in the short to medium-term (Veiga et al., 2016). This reinforces the unanimous claim of experts across Europe that the implementation of the LO in small-scale fisheries will generate economic losses to the fishing industry and a consequent struggle for fishers to continue fishing, as well as losses of direct and indirect jobs (Villasante et al., 2016b). Such impacts are highly probable in the Azores, but would likely be heterogeneous within the archipelago due to strong cultural and socio-economic contrasts between different islands (Neilson et al., 2014), possibly leading to differences in fishing pressure and state of fish populations. In the islands where the quota is collective, fishers would prefer individual quota that they could manage as they want. Results of a bio-economic model indeed showed that economic and stock benefits are expected to be higher with ITQ compared to collective TAC quota, independently of the LO, but higher economic benefits of the LO can be expected when quotas are collective compared with ITQ (Frost and Hoff, 2017). ITQ can result in increased discards, especially if at-sea enforcement is low (Branch, 2009), and as such might not be fully appropriate to mitigate the impacts of the LO. Contrary to other interviewed European small-scale fishers (Villasante et al., 2016b), Azorean fishers were mostly satisfied with the TAC system and not willing to change for a system of effort control.

In spite of a strong disagreement regarding the LO, it is likely that it would be more efficiently implemented if fishers are involved and participate in the implementation process(de Vos et al., 2016; Eliasen et al., 2014), and if sufficient flexibility is provided to find their own solutions in reducing unwanted catch (Catchpole et al., 2017). Fishers' ecological knowledge is complementary to scientific knowledge and has been proven helpful to build sound management measures (Gaspare et al., 2015; Martins et al., 2018; Zukowski et al., 2011). Azorean fishers showed interest in working in collaboration with scientists and highlighted specific needs tailored to support the unfit of the LO to the Azorean situation, revealing a good understanding on how fisheries management works and their willingness for a sound management of their fishery. Accurate knowledge of catch and discard, and associated observer programmes, were also recognized to be essential to improve knowledge on fishing practices and support fishers' empirical knowledge (Vos et al., 2016), specifically in what concerns selectivity, discard and survival rates. 


\subsection{Conclusion}

Results of this study suggest that future compliance of the LO in the Azorean small-scale deep-water bottom fishery is likely to be low as they do not believe it will bring any benefits to them or to the fisheries resources. This result mimics those found for many small-scale European fisheries (Maynou et al., 2018; Villasante et al., 2019, 2016b). The LO was mostly perceived as unfit to the specificities of the local fishery as: i) fishers are using the most selective fishing gear possible, ii) survival of discarded species is believed to be high, iii) their potential fishing grounds are limited by the great surroundings depths of the seafloor, and iv) they are in an outermost region where fisheries are central to the local economy and need to be given special attention due to their isolation and vulnerability.

In the recent years, the number of licences granted by the Azorean Regional Government to bottom longliners has declined while it remained constant for handliners. Indeed, this gear conversion has contributed to a higher selectivity of the fishery, lower discarding, and higher potential for bycatch avoidance. Handlining provides higher flexibility and adaptability to fishing conditions than longlining. Deep-water sharks are rarely caught with handlines and are more likely to survive after release, which is positive in terms of conservation given the high vulnerability of those species (Das and Afonso, 2017; Garcia et al., 2008). From an economic perspective, the advantages of converting to handlining are reduced costs (employment/crew, bait, number of hooks, fuel, etc.) and higher selling prices due to better fish condition. From a social perspective though, this conversion likely has detrimental effects on employment as the number of crew members needed by handliners is much lower than by longliners. This does not only include crew members on board, but also inland crew (including many women) that are hired by longliners to prepare/bait the gear. Another potential risk of this gear conversion lies in the fact that because the catch diversity of handliners is lower, fishing pressures could increase and concentrate on a limited number of target species. Appropriate monitoring should therefore be assured in order to ascertain that exploitation levels do not pose risks to those populations.

Other options to further improve selectivity and avoid unwanted catch seem limited in Azorean fisheries. Local fishers expected that survival and de minimis exemptions could help them adapt to the LO and limit its socio-economic impacts. These type of exemptions have been widely asked and granted elsewhere (Borges et al., 2016). As a result, in May 2018 the Regional Government of the Azores with data provided by the H2020 Discardless project submitted to the Scientific, Technical and Economic Committee for Fisheries (STECF) secretariat a document supporting evidence for requesting high survival exemption for blackspot seabream (Pagellus bogaraveo) and de minimis exemptions for alfonsinos (Beryx spp.) and greater forkbeard (Phycis blennoides) caught by the hooks-and-lines fisheries in ICES sub-area X. STECF (2018) considered that there was enough evidence for difficulties in further improving selectivity and for the disproportionate costs of handling the unwanted catch, and sound scientific evidence supporting high survival of blackspot seabream following discarding. Those exemptions were approved by the European Commission in 2018 (EU 2018/2033). 


\section{Acknowledgements}

The authors would like to express their gratitude to all fishermen who kindly participated in the interviews and all colleagues who helped prepare and organize them, especially Carla Dâmaso, Nuno Pereira, Paulo Ávila, Gonçalo Graça, Dave Reid and Julia Calderwood. We would like to thank three anonymous reviewers for their comments which contributed to improve the manuscript.

Funding: This work was supported by the European Union's Horizon 2020 research and innovation programme [Grant Agreement DiscardLess No 633680]; the Fundação para a Ciência e Tecnologia (FCT) and FEDER [strategic project UID/MAR/04292/2013 granted to MARE; and UID/AMB/50017/2019 to CESAM]; FCT programa Investigador IF/01194/2013/CP1199/CT0002 granted to TM; FCT/MCTES and FEDER Funds [Grant Agreement LESSisMORE, Ref. PTDC/ASP-PES/28179/2017 granted to CP].

\section{References}

Abecasis, R.C., Afonso, P., Colaço, A., Longnecker, N., Clifton, J., Schmidt, L., Santos, R.S., 2015. Marine Conservation in the Azores: Evaluating Marine Protected Area Development in a Remote Island Context. Frontiers in Marine Science 2. https://doi.org/10.3389/fmars.2015.00104

Afonso, P., Graça, G., Berke, G., Fontes, J., 2012. First observations on seamount habitat use of blackspot seabream (Pagellus bogaraveo) using acoustic telemetry. Journal of Experimental Marine Biology and Ecology 436-437, 1-10. https://doi.org/10.1016/j.jembe.2012.08.003

Afonso, P., Schmiing, M., Fontes, J., Tempera, F., Morato, T., S. Santos, R., 2018. Effects of marine protected areas on coastal fishes across the Azores archipelago, mid-North Atlantic. Journal of Sea Research 138, 34-47. https://doi.org/10.1016/j.seares.2018.04.003

Alzorriz, N., Jardim, E., Poos, J.J., 2018. Likely status and changes in the main economic and fishery indicators under the landing obligation: A case study of the Basque trawl fishery. Fisheries Research 205, 86-95. https://doi.org/10.1016/j.fishres.2018.04.004

Armstrong, D.W., Ferro, R.S.T., MacLennan, D.N., Reeves, S.A., 1990. Gear selectivity and the conservation of fish. J. Fish. Biol. 37, 261-262.

Batsleer, J., Rijnsdorp, A.D., Hamon, K.G., van Overzee, H.M.J., Poos, J.J., 2016. Mixed fisheries management: Is the ban on discarding likely to promote more selective and fuel efficient fishing in the Dutch flatfish fishery? Fisheries Research 174, 118-128. https://doi.org/10.1016/j.fishres.2015.09.006

Bellido, J.M., García-Rodriguez, M., García-Jiménez, T., González-Aguilar, M., CarbonellQuetglas, A., 2017. Could the obligation to land undersized individuals increase the black market for juveniles: evidence from the Mediterranean? Fish and Fisheries 18, 185-194. https://doi.org/10.1111/faf.12166

Borges, L., Cocas, L., Nielsen, K.N., 2016. Discard ban and balanced harvest: a contradiction? ICES Journal of Marine Science: Journal du Conseil 73, 1632-1639. https://doi.org/10.1093/icesjms/fsw065

Branch, T.A., 2009. How do individual transferable quotas affect marine ecosystems? Fish and Fisheries 10, 39-57. https://doi.org/10.1111/j.1467-2979.2008.00294.x 
Canha, Â., 2013. Caracterização das rejeições na pescaria de demersais nos Açores. (Master Thesis). University of the Azores, Department of Oceanography and Fisheries, Horta, Portugal.

Carvalho, N., 2010. Sea to shore: an economic evaluation of the Azorean Commercial Fisheries (PhD thesis). University of the Azores, Horta, Portugal.

Carvalho, N., Edwards-Jones, G., Isidro, E., 2011. Defining scale in fisheries: Small versus largescale fishing operations in the Azores. Fisheries Research 109, 360-369. https://doi.org/10.1016/j.fishres.2011.03.006

Catchpole, T.L., Feekings, J.P., Madsen, N., Palialexis, A., Vassilopoulou, V., Valeiras, J., Garcia, T., Nikolic, N., Rochet, M.-J., 2014. Using inferred drivers of discarding behaviour to evaluate discard mitigation measures. ICES Journal of Marine Science 71, 1277-1285. https://doi.org/10.1093/icesjms/fst170

Catchpole, T.L., Frid, C.L.J., Gray, T.S., 2005. Discards in North Sea fisheries: causes, consequences and solutions. Mar. Policy 29, 421-430.

Catchpole, T.L., Ribeiro-Santos, A., Mangi, S.C., Hedley, C., Gray, T.S., 2017. The challenges of the landing obligation in EU fisheries. Marine Policy 82, 76-86. https://doi.org/10.1016/j.marpol.2017.05.001

Christou, M., Haralabous, J., Stergiou, K.I., Damalas, D., Maravelias, C.D., 2017. An evaluation of socioeconomic factors that influence fishers' discard behaviour in the Greek bottom trawl fishery. Fisheries Research 195, 105-115. https://doi.org/10.1016/j.fishres.2017.07.003

Condie, H.M., Grant, A., Catchpole, T.L., 2014. Incentivising selective fishing under a policy to ban discards; lessons from European and global fisheries. Marine Policy 45, 287-292. https://doi.org/10.1016/j.marpol.2013.09.001

Condie, H.M., Grant, A., Catchpole, T.L., 2013. Does banning discards in an otter trawler fishery create incentives for more selective fishing? Fisheries Research 148, 137-146. https://doi.org/10.1016/j.fishres.2013.09.011

Das, D., Afonso, P., 2017. Review of the Diversity, Ecology, and Conservation of Elasmobranchs in the Azores Region, Mid-North Atlantic. Frontiers in Marine Science 4, 354. https://doi.org/10.3389/fmars.2017.00354

de Vos, B.I., Döring, R., Aranda, M., Buisman, F.C., Frangoudes, K., Goti, L., Macher, C., Maravelias, C.D., Murillas-Maza, A., van der Valk, O., Vasilakopoulos, P., 2016. New modes of fisheries governance: Implementation of the landing obligation in four European countries. Marine Policy 64, 1-8. https://doi.org/10.1016/j.marpol.2015.11.005

Diogo, H., Pereira, J.G., Higgins, R.M., Canha, Â., Reis, D., 2015. History, effort distribution and landings in an artisanal bottom longline fishery: An empirical study from the North Atlantic Ocean. Marine Policy 51, 75-85. https://doi.org/10.1016/j.marpol.2014.07.022

Dunn, D.C., Boustany, A.M., Halpin, P.N., 2011. Spatio-temporal management of fisheries to reduce by-catch and increase fishing selectivity. Fish and Fisheries 12, 110-119.

Eliasen, S.Q., Bichel, N., 2016. Fishers sharing real-time information about "bad" fishing locations. A tool for quota optimisation under a regime of landing obligations. Marine Policy 64, 16-23. https://doi.org/10.1016/j.marpol.2015.11.007

Eliasen, S.Q., Papadopoulou, K.-N., Vassilopoulou, V., Catchpole, T.L., 2014. Socio-economic and institutional incentives influencing fishers' behaviour in relation to fishing practices and discard. ICES J. Mar. Sci. 71, 1298-1307. https://doi.org/10.1093/icesjms/fst120

Fagundes, M.B., Vendruscolo, R.G., Maroneze, M.M., Barin, J.S., de Menezes, C.R., Zepka, L.Q., Jacob-Lopes, E., Wagner, R., 2018. Towards a Sustainable Route for the Production 
of Squalene Using Cyanobacteria. Waste and Biomass Valorization. https://doi.org/10.1007/s12649-017-0191-8

FAO, 1996. Report of the technical consultation on reduction of wastage in fisheries. Tokyo, Japan, 28 October - 1 November 1996 (FAO Fisheries Report No. 547). FAO, Rome.

Fauconnet, L., Pham, C.K., Canha, A., Afonso, P., Diogo, H., Machete, M., Silva, H.M., Vandeperre, F., Morato, T., 2019. An overview of fisheries discards in the Azores. Fisheries Research 209, 230-241. https://doi.org/10.1016/j.fishres.2018.10.001

Fauconnet, L., Pham, C.K., Canha, Â., Afonso, P., Vandeperre, F., Machete, M., Reis, D., Pereira, J.G., Morato, T., in press. An overview of fisheries discards in the Azores. Fisheries Research.

Fitzpatrick, M., Frangoudes, K., Fauconnet, L., Quetglas, A., 2019. Fishing Industry Perspectives on the EU Landing Obligation, in: Uhlmann, S.S., Ulrich, C., Kennelly, S.J. (Eds.), The European Landing Obligation. Springer International Publishing, Cham, pp. 71-87. https://doi.org/10.1007/978-3-030-03308-8_4

Fitzpatrick, M., Quetglas, T., Frangoudes, K., Nielsen, K.N., 2017. Policy Brief 2: Year 2 Of The Landing Obligation, Key Issues In Mediterranean Fisheries. Zenodo. https://doi.org/10.5281/zenodo.573666

Fontes, J., Rosa, A., Graça, G., Giacomello, E., Cardenal, R., Afonso, P., Menezes, G.M., 2015. Can Deep Sea Sharks respond to short term protection? Looking into the deep.

Frost, H.S., Hoff, A., 2017. The landing obligation in view of different management regimes. Fisheries Research 195, 202-213. https://doi.org/10.1016/j.fishres.2017.07.013

Garcia, V.B., Lucifora, L.O., Myers, R.A., 2008. The importance of habitat and life history to extinction risk in sharks, skates, rays and chimaeras. Proceedings of the Royal Society B: Biological Sciences 275, 83-89. https://doi.org/10.1098/rspb.2007.1295

Gaspare, L., Bryceson, I., Kulindwa, K., 2015. Complementarity of fishers' traditional ecological knowledge and conventional science: Contributions to the management of groupers (Epinephelinae) fisheries around Mafia Island, Tanzania. Ocean \& Coastal Management 114, 88-101. https://doi.org/10.1016/j.ocecoaman.2015.06.011

Ingólfsson, Ó.A., Einarsson, H.A., Løkkeborg, S., 2017. The effects of hook and bait sizes on size selectivity and capture efficiency in Icelandic longline fisheries. Fisheries Research 191, 10-16. https://doi.org/10.1016/j.fishres.2017.02.017

Kraak, S.B.M., Reid, D.G., Bal, G., Barkai, A., Codling, E.A., Kelly, C.J., Rogan, E., 2015. RTI ("Real-Time Incentives") outperforms traditional management in a simulated mixed fishery and cases incorporating protection of vulnerable species and areas. Fisheries Research 172, 209-224. https://doi.org/10.1016/j.fishres.2015.07.014

Krug, H.M., 1998. Variation in the reproductive cycle of the blackspot seabream, Pagellus bogaraveo (Brünnich, 1768) in the Azores. ARQUIPÉLAGO-Life and Marine Sciences $16 \mathrm{~A}, 37-47$.

Lewis, J., Williams, M., 1994. Regional autonomy and the European communities: The view from Portugal's Atlantic Islands. Regional Politics and Policy 4, 67-85.

Maina, I., Kavadas, S., Machias, A., Tsagarakis, K., Giannoulaki, M., 2018. Modelling the spatiotemporal distribution of fisheries discards: A case study on eastern Ionian Sea trawl fishery. Journal of Sea Research 139, 10-23. https://doi.org/10.1016/j.seares.2018.06.001

Martins, I.M., Medeiros, R.P., Di Domenico, M., Hanazaki, N., 2018. What fishers' local ecological knowledge can reveal about the changes in exploited fish catches. Fisheries Research 198, 109-116. https://doi.org/10.1016/j.fishres.2017.10.008 
Maynou, F., Gil, M. del M., Vitale, S., Giusto, G.B., Foutsi, A., Rangel, M., Rainha, R., Erzini, K., Gonçalves, J.M.S., Bentes, L., Viva, C., Sartor, P., De Carlo, F., Rossetti, I., Christou, M., Stergiou, K., Maravelias, C.D., Damalas, D., 2018. Fishers' perceptions of the European Union discards ban: perspective from south European fisheries. Marine Policy 89, 147-153. https://doi.org/10.1016/j.marpol.2017.12.019

Menezes, G., 1996. Interacções tecnológicas na pesca demersal dos Açores. (“APCC” thesis (Masters thesis equivalent)). University of the Azores, Department of Oceanography and Fisheries, Portugal.

Morandeau, G., Macher, C., Sanchez, F., Bru, N., Fauconnet, L., Caill-Milly, N., 2014. Why do fishermen discard? Distribution and quantification of the causes of discards in the Southern Bay of Biscay passive gear fisheries. Mar. Policy 48, 30-38. https://doi.org/10.1016/j.marpol.2014.02.022

Morato, T., 2012. Description of environmental issues, fish stocks and fisheries in the EEZs around the Azores and Madeira.

Morato, T., Kvile, K. ø., Taranto, G.H., Tempera, F., Narayanaswamy, B.E., Hebbeln, D., Menezes, G.M., Wienberg, C., Santos, R.S., Pitcher, T.J., 2013. Seamount physiography and biology in the north-east Atlantic and Mediterranean Sea. Biogeosciences 10, 30393054. https://doi.org/10.5194/bg-10-3039-2013

Morato, T., Machete, M., Kitchingman, A., Tempera, F., Lai, S., Menezes, G., Pitcher, T., Santos, R., 2008. Abundance and distribution of seamounts in the Azores. Marine Ecology Progress Series 357, 17-21. https://doi.org/10.3354/meps07268

Morgan, M.G., Fishhoff, B., Bostrom, A., Atman, C.J., 2002. Risk communication: A mental models approach, Cambridge. ed. Cambridge University Press, New York.

Neilson, A.L., Gabriel, R., Arroz, A.M., Mendonça, E., 2014. Perspectives about the Sea in the Azores: Respecting Narratives that Sustain Inshore Fishing Communities, in: Urquhart, J., Acott, T.G., Symes, D., Zhao, M. (Eds.), Social Issues in Sustainable Fisheries Management. Springer Netherlands, Dordrecht, pp. 319-338. https://doi.org/10.1007/978-94-007-7911-2_17

Paradinas, I., Marín, M., Grazia Pennino, M., López-Quílez, A., Conesa, D., Barreda, D., Gonzalez, M., María Bellido, J., 2016. Identifying the best fishing-suitable areas under the new European discard ban. ICES Journal of Marine Science: Journal du Conseil 73, 2479-2487. https://doi.org/10.1093/icesjms/fsw114

Pham, C.K., Canha, A., Diogo, H., Pereira, J.G., Prieto, R., Morato, T., 2013. Total marine fishery catch for the Azores (1950-2010). ICES Journal of Marine Science 70, 564-577. https://doi.org/10.1093/icesjms/fst024

Pinho, M., Diogo, H., Carvalho, J., Pereira, J.G., 2014. Harvesting juveniles of blackspot sea bream (Pagellus bogaraveo) in the Azores (Northeast Atlantic): biological implications, management, and life cycle considerations. ICES Journal of Marine Science 71, 24482456. https://doi.org/10.1093/icesjms/fsu089

Poos, J.J., Bogaards, J.A., Quirijns, F.J., Gillis, D.M., Rijnsdorp, A.D., 2010. Individual quotas, fishing effort allocation, and over-quota discarding in mixed fisheries. ICES J. Mar. Sci. 67, 323-333.

Prellezo, R., Carmona, I., García, D., 2016. The bad, the good and the very good of the landing obligation implementation in the Bay of Biscay: A case study of Basque trawlers. Fisheries Research 181, 172-185. https://doi.org/10.1016/j.fishres.2016.04.016

Reid, D., Calderwood, J., Fauconnet, L., Morato, T., Afonso, P., Frangoudes, K., Triantaphyllidis, G., Argyrou, I., Plet-Hansen, K.S., Mortensen, L.O., Quetglas, T., Vermard, Y., Pointin, F., Vaz, S., Robert, M., Fitzpatrick, M., 2017. Initial Avoidance Manuals By Case Study 
Including Tactical, Strategic And Gear Based Approaches Agreed By Scientists And Fishers (DiscardLess Deliverable No. 4.1). Zenodo. https://doi.org/10.5281/zenodo.1204181

Salierno, J.D., Overton, A.S., Benson, C.L., 2018. Optimization of Hook Size to Reduce Discards and Injury in the New Jersey Summer Flounder Hook-and-Line Fishery. North American Journal of Fisheries Management 38, 393-399. https://doi.org/10.1002/nafm.10046

Sardà, F., Coll, M., Heymans, J.J., Stergiou, K.I., 2015. Overlooked impacts and challenges of the new European discard ban. Fish and Fisheries 16, 175-180. https://doi.org/10.1111/faf.12060

Sousa, F., Isidro, E., Erzini, K., 1999. Semi-pelagic longline selectivity for two demersal species from the Azores: the black spot sea bream (Pagellus bogaraveo) and the bluemouth rockfish (Helicolenus dactylopterus dactylopterus). Fisheries research 41, 25-35.

Tashakkori, A., Teddlie, C., 2003. Handbook of Mixed Methods Sampling in Social and Behavioural Research. Sage Publications, Thousand Oaks, California.

Veiga, P., Pita, C., Rangel, M., Gonçalves, J.M.S., Campos, A., Fernandes, P.G., Sala, A., Virgili, M., Lucchetti, A., Brčić, J., Villasante, S., Ballesteros, M.A., Chapela, R., Santiago, J.L., Agnarsson, S., Ögmundarson, Ó., Erzini, K., 2016. The EU landing obligation and European small-scale fisheries: What are the odds for success? Marine Policy 64, 64-71. https://doi.org/10.1016/j.marpol.2015.11.008

Villasante, S., Antelo, M., Christou, M., Fauconnet, L., Frangoudes, K., Maynou, F., Morato, T., Pita, C., Pita, P., Stergiou, K.I., Teixeira, C., Tserpes, G., Vassilopoulou, V., 2019. The Implementation of the Landing Obligation in Small-Scale Fisheries of Southern European Union Countries, in: Uhlmann, S.S., Ulrich, C., Kennelly, S.J. (Eds.), The European Landing Obligation. Springer International Publishing, Cham, pp. 89-108. https://doi.org/10.1007/978-3-030-03308-8_5

Villasante, S., Pierce, G.J., Pita, C., Guimeráns, C.P., Rodrigues, J.G., Antelo, M., Da Rocha, J.M., Cutrín, J.G., Hastie, L.C., Veiga, P., Sumaila, U.R., Coll, M., 2016a. Fishers' perceptions about the EU discards policy and its economic impact on small-scale fisheries in Galicia (North West Spain). Ecological Economics 130, 130-138.

Villasante, S., Pita, C., Pierce, G.J., Guimeráns, C.P., Rodrigues, J.G., Antelo, M., Rocha, J.M.D., Cutrín, J.G., Hastie, L., Sumaila, U.R., Coll, M., 2016b. To land or not to land: How do stakeholders perceive the zero discard policy in European small-scale fisheries? Marine Policy 71, 166-174. https://doi.org/10.1016/j.marpol.2016.05.004

Welch, H., Pressey, R.L., Reside, A.E., 2018. Using temporally explicit habitat suitability models to assess threats to mobile species and evaluate the effectiveness of marine protected areas. Journal for Nature Conservation 41, 106-115. https://doi.org/10.1016/j.jnc.2017.12.003

Zukowski, S., Curtis, A., Watts, R.J., 2011. Using fisher local ecological knowledge to improve management: The Murray crayfish in Australia. Fisheries Research 110, 120-127. https://doi.org/10.1016/j.fishres.2011.03.020 